\title{
Some Problems in the Conversion of a College to a University Library
}

While the statistical planning process involved in converting a college to a university library has been described and documented in a few articles, several interesting points bearing on this transition have either been for the most part omitted or touched on only lightly in the library literature. Since some of these points may be very perplexing, such as microcopy materials and book fund allocations, they would seem to merit mention. In addition, certain subjects concerning book selection, intra-campus library administration and cooperation, and the status of librarians are worthy of further discussion because they have general application not only to the conversion of a college to a university library, but in the development of a university library, be it new or well established.

\begin{abstract}
Among the most challenging responsibilities to confront academic librarians must surely be either the establishment of a new university library or the conversion of a college to a university library. Both situations have been discussed in the library literature (usually treated separately), but too often the discussions have centered on statistical guidelines for the planning process. Often overlooked or only casually mentioned have been some of the problematic decisions and resulting implementation problems that librarians must face in either of these situations. While this paper will deal more with the conversion of a college to a university library, these same points may be germane to establishing a new university library.
\end{abstract}

Mr. Haro is Librarian of the Institute of Governmental Affairs in the University of California at Davis.

\section{Quality of Library Materials}

Within the framework of developing a library's collection(s) from a college to a university level, little mention has been made concerning the quality of library materials and the need for selectivity. It is relatively simple to assemble extensive bibliographies and lists of items that, within various disciplines, should be represented in a good university library collection. Unfortunately, time and money are two precious commodities that the librarian usually has too little of during the conversion state. Too often the quality of library materials is sacrificed to readily available materials, lack of funds, a haste to encumber allocated funds, administrative and faculty pressures, and purely statistical considerations concerning proposed size of enrollment, or research and teaching programs. The statement, "Institutions should not plan library facilities based largely on the size of enrollment," should 
continue, "nor should institutions plan library facilities based solely on the number of books per students, staff, or faculty." While for the sake of long-range financial planning it may be necessary to rely largely on quantitative measures, a method of selection to ensure the quality of library materials secured should be investigated and implemented. No one list or a combination of library material lists can be safely utilized as a purchasing guide without the careful deletion and the addition or substitution of recent materials to achieve orderly, comprehensive, and qualitative collection growth within financial limitations. Margit Kraft, in her article, "An argument for selectivity in the acquisition of materials for research libraries," devotes considerable attention to the need for quality in developing and maintaining a library's collection( $\mathrm{s}) .^{1}$

It is into this situation that the talents of a subject specialist or a subject bibliographer should be injected. The subject specialist is best suited to assist in planning the library's collection(s) and to make objective judgments concerning which items to purchase and which to reject. The important element to remember here is that the careful choice of library materials to provide the patron with needed information should be the library's first goal. Mary Lee Bundy and Paul Wasserman addressed themselves to this topic when they wrote:

. . . the most effective client service may well be enhanced when the librarian concentrates his efforts upon careful discrimination in choice of acquisitions rather than in fiercely competitive and feverish collection building. Ultimately, means become ends; libraries are measured in terms of the size of their collections while the more significant measure, the quality and the nature of the services they render, is ignored. ${ }^{2}$

${ }^{1}$ Library Trends, XXXVII (July 1967), 284-95.

${ }^{2}$ Mary Lee Bundy and Paul Wasserman, "Professionalism Reconsidered," College \& Research Libraries, XXIX (January 1968), 10.
In addition to his book selection responsibilities, the library subject specialist should be utilized as a coordinator between the library and faculty/research staff concerning such matters as planning library collection development, i.e., new area studies programs.

\section{AREA AND/OR INTERdisciplinary StUdies}

In the library literature, very little mention is made about planning for area or interdisciplinary studies and programs. Yet during the conversion of a college to a university library such programs logically should be considered by the librarian and discussed with the campus administrative officers. The reasons for not doing so may be because accurate statistics are not widely available on the costs or size of collections needed, or because such concentrations may fall under a graduate program, or perhaps under an interdepartmental one. Regardless of how such an area or interdisciplinary studies program is organized and taught, it frequently represents a considerable expense that the library should be aware of and plan for. Some of the difficulties for libraries caused by these programs were presented by T. H. Tsien and $\mathrm{H}$. W. Winger.

The area-study programs have presented special problems for the library, especially the university and research libraries. Not only do those previously neglected areas of interest require extensive library support, but the interdisciplinary approach of area studies is at variance with traditional library practices in organization, administration, and services. ${ }^{3}$

Perhaps the major deficiency in the way libraries handle area or interdisciplinary studies results from either a lack of, or inadequate planning resulting in, insufficient funds not only for the purchase of materials, but also for

\footnotetext{
${ }^{3}$ T. H. Tsien and H. W. Winger, "Area Studies and Library Resources," Library Quarterly, XXXV (October 1965), 203.
} 
the securing of staff with subject and language competence.

\section{Microcopy Materials}

Very often inadequate planning is given to microcopy materials. Statistics on desirable goals for microcopy materials are not widely available even though these items represent a significant part of most university libraries' collections. These materials become more important when one considers that many back-files of serials, reports, public documents, and even monographs are not available in any format other than microcopy. Nevertheless, librarians frequently ignore or plan poorly for these materials. Robert C. Sullivan, in his article, "Library Microfilm Rate Indexes," wrote the following on just one aspect of this problem:

It is surprising in talking to librarians how little some of them know about the availability and cost of microfilm. While many librarians have a general knowledge of microfilm, it is evident that some do not relate this potential to their own position or responsibility to their own institutions. ${ }^{4}$

Librarians should be realistic in accepting microcopy as an important part of a university's library; they should budget carefully for these materials and plan adequate quarters and service facilities for them.

\section{Problems of Out-of-Print Books}

Developing universities must also plan carefully for the acquisition of out-ofprint materials. Eldred Smith, in his article, "Out-of-print Booksearching," addressed himself to the need for greater attention to out-of-print procedures. $\mathrm{He}$ wrote:

One of the most curious features of this era of unprecedented library expansion is the comparatively slight attention that is being

\footnotetext{
4 Robert C. Sullivan, "Library Microfilm Rate Indexes," Library Resources \& Technical Services, XI (Winter 1967), 115-19.
}

given to the problems and procedures of out-of-print booksearching. No matter how much one may subscribe to the argument that research libraries must give primary emphasis to the acquisition of in-print materials, out-of-print needs cannot be ignored. ${ }^{5}$

Smith presents in this article a program for out-of-print searching that librarians whether establishing or converting a college to a university library should be aware of. Out-of-print searching, while a necessary and expensive procedure, can be profitable and rewarding if librarians establish close contacts with reliable out-of-print dealers and make known their needs, especially for en bloc collections, rather than rely merely on dealers' lists. Unfortunately, Smith is quite correct when he states that most college and research libraries still approach their out-of-print needs on a "catch-as-catch-can" basis. The most opportune time to design and implement a rational out-of-print program would seem to be in the planning state of converting a college to a university library, or in establishing a new university library.

\section{Library Organization}

Perhaps hundreds of articles have been written on the need for effective academic library organization that are germane to planning the conversion of a college to a university library. The present paper chooses to discuss two often ignored aspects of library organization within this context: centralization of library services, and the status of librarians.

Centralization. Whether one agrees or not with the need for centralizing library services under the control of the university librarian, there can sometimes be economical and political considerations that may necessitate digres-

${ }^{5}$ Eldred Smith, "Out-of-print Booksearching," College \& Research Libraries, XXIX (July 1968), 303. 
sion from such a policy. There are, for example, on the various university campuses across the United States, a growing number of research centers with libraries not under the jurisdiction or control of the university librarian. ${ }^{6}$ These libraries range in size from a few thousand titles to over three hundred thousand cataloged items in the University of California's Institute of Govermental Studies Library on the Berkeley campus. $^{7}$ As specialized libraries they serve a different function than do the main libraries and their branches. They handle mainly ephemera and fugitive materials and provide more intensive service to their research staff and clientele than the main library systems could do economically. Unfortunately, while these libraries neither compete nor overlap with the main library systems in the type of materials secured and library services offered, they frequently fail to cooperate. Their holdings, especially current serial titles received, are often not listed in the main card catalogs or in combined serial title holding lists for the various campuses. The increase in these separate research center libraries, particularly in the fields of government, public, and urban affairs, indicates the intensive research material demands of research staff and the apparent inability of most university libraries to secure, process, and make available economically, the non-book materials need by faculty and research staff attached to these research centers. University librarians can neither resist nor ignore these research center libraries. They should, of course, cooperate with the directors of these centers and their librarians, for through cooperation and planning, all available information resources and services on their campuses would be made available to library users, a situation

${ }^{6}$ See Fig. 1 on government, public affairs, and urban studies research center libraries.

7 News Notes of California Libraries, LXIII (Winter 1968), 108-109.

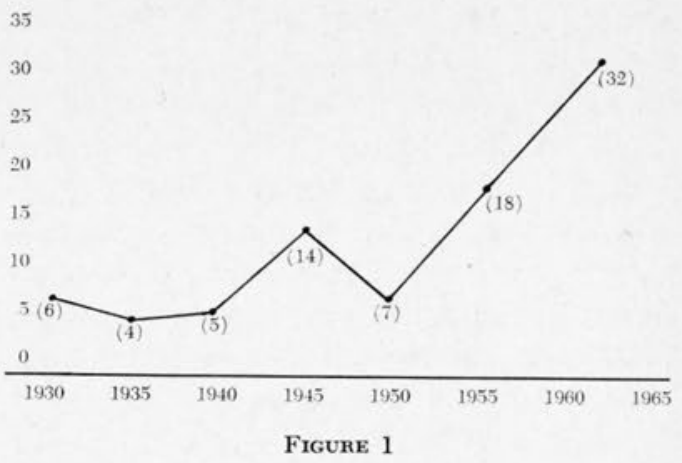

Note: This graph indicates the trend in the establishment of libraries in the fields of governmental, public and urban affairs at American college and universities since 1930. All of the libraries surveyed for this graph were attached to a research bureau, center, or institute and were administratively controlled by, and responsible to, the director of the respective research bureau, center or institute. In the area of urban studies alone, more of these research centers and their specialized libraries were being established at new universities than at older ones.

It is interesting to note that since 1965, approximately twenty-eight new libraries in the three fields listed above have been established. This provocative trend is subject to various interpretations with regard to library service and academic research.

Statistics for this graph were taken from Robert P. Haro, A Directory of Governmental, Public and Urban Affairs Research Centers at American Colleges and Universities. (Davis, California: Institute of Governmental Affairs, University of California, 1968.)

that is sometimes not the case at present.

Status of librarians. It is probably true that the closer librarians are in status to the faculty, the easier it is for them to work with the faculty and research staff and to secure their confidence in library matters. During the conversion of a college to a university library and especially in planning a new university library, an excellent opportunity to achieve faculty status for librarians arises. However, little mention is made of this fact in articles discussing faculty status for librarians. Most discussion in the library literature centers on why librarians should have faculty status, but there is little available on how and when to press for faculty status. ${ }^{8}$ Perhaps librarians may be unwilling to risk such a venture or a confrontation on this point during the

${ }^{8}$ But see Harold D. Jones, "LACUNY: a Library Association in Action," California Librarian, XXIX (July 1968), 209. 
planning stage, but procrastination in seeking a decision on faculty status could be a tactical error. Administrative problems will always increase, not decrease, in the future and make a decision, especially a favorable one on faculty status seem less important to university administrators. There can be many valid reasons for specific institutions to lack faculty status for librarians; however, where possible, a librarian should be willing to risk a confrontation to achieve this goal for his colleagues which will in the long run mean better service and a better library staff.

\section{Book Fund Allocation}

One of the most perplexing problems faced by librarians is control of the book funds. A university librarian, especially at a new or developing institution, should, in the eyes of some, actively seek to transfer the allocation of book funds to library control to achieve effective and orderly library development and avoid future headaches. This one responsibility is a major problem area in planning the rapid and systematic transition or development of a library's collection(s). When funds are controlled by the faculty, vociferous academic departments sometimes secure large book fund allocations which they cannot in fact spend by the required time. This can cause undue haste on the part of the library to encumber the remaining funds at a last minute. It may be possible to plan for this situation with prepared batches of priority orders in a holding file. However, orderly and effective purchasing is often defeated by the unknown amounts of funds that may remain uncommitted to a late date and their sudden and impromptu availability. The allocation of book funds may be a hornet's nest for some academic librarians, but it is of sufficient importance to merit the librarian's careful consideration in the planning process of developing a university library.

The problems that have been discussed here are not the only ones that librarians must face either in converting a college to a university library or in establishing a new university library. They do, however, represent some of the thornier questions that librarians sometimes face and, remarkably, they are things that are seldom discussed in the library literature, especially with reference to the above two situations. Risky and difficult as some of these decisions may be for the librarian, the planning stage is the best time to make them. If they are put off, they will loom larger with the passage of time.

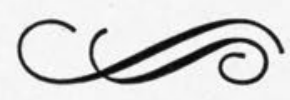

